$\underline{\text { Artikel Penelitian }}$

\title{
Konsumsi Junk food dan Serat pada Remaja Putri Overweight dan Obesitas yang Indekos
}

\section{Junk food and Fiber Consumption among Overweight and Obese Young Women Living in Boarding House}

\author{
Pipit Septiana ${ }^{1}$, Fajar Ari $N^{2}$, Catur Saptaning $W^{2}$ \\ ${ }^{1}$ Program Pendidikan IImu Gizi Fakultas Kedokteran Universitas Brawijaya Malang \\ ${ }^{2}$ Laboratorium IImu Gizi Fakultas Kedokteran Universitas Brawijaya Malang
}

\begin{abstract}
ABSTRAK
Seiring dengan perkembangan zaman angka kejadian overweight dan obesitas remaja semakin meningkat. Remaja dengan obesitas memiliki kebiasaan konsumsi makanan tinggi kalori dan rendah serat. Penelitian ini bertujuan untuk mengetahui bagaimana konsumsi junk food dan serat pada remaja putri dengan overweight dan obesitas yang indekos. Penelitian ini merupakan penelitian kualitatif yang dilakukan di wilayah Sumber Sari dan Kerto, Malang. Sampel dipilih dengan metode purposive sampling yang terdiri dari 9 orang informan kunci dan 14 orang teman informan kunci sebagai triangulasi untuk menjamin validitas data. Data dikumpulkan dengan metode wawancara mendalam dan observasi dibantu dengan catatan, tape recorder, dan kamera. Hasil penelitian menunjukkan bahwa frekuensi konsumsi junk food pada informan tergolong tinggi dengan jenis junk food yang sering dikonsumsi fried chicken. Alasan tingginya konsumsi junk food paling utama adalah alasan rasa. Frekuensi konsumsi serat informan juga masih rendah dengan jenis serat yang sering dikonsumsi adalah lalapan. Alasan utama rendahnya konsumsi serat karena keterbatasan ketersediaan makanan sumber serat. Kesimpulan dari penelitian ini adalah konsumsi junk food pada remaja putri indekos dengan overweight dan obesitas masih tinggi dan konsumsi serat informan masih begitu rendah.
\end{abstract}

Kata Kunci: Indekos, konsumsi junkfood, konsumsi serat, remaja putri

\begin{abstract}
Over the time, the incidence of overweight and obesity among adolescents is increasing. Adolescents with obesity have a habit of eating foods high in calories but low in fiber. This research aimed to determine the consumption of junk food and fiber in overweight and obese young women who live in boarding house. This qualitative study was conducted on Sumbersari and Kerto, Malang. Samples were selected by purposive sampling consisting of 9 key informants and 14 friends as triangulation to ensure data validity. Data were collected with in-depth interviews and observations assisted with notes, tape recorders, and cameras. The results indicate that the frequency of junk food consumption in the informants is high and the most junk food consumed was fried chicken. The main reason for the high consumption of junk food is the taste. The frequency of fiber consumption among informants is low, and type of fiber most consumed is fresh vegetables. The main reason of low fiber consumption is due to limited availability of fiber sources. It is concluded that junk food consumption in overweight and obese young women who live in boarding house is high while fiber consumption is low.
\end{abstract}

Keyword: Fiber consumption, junkfood consumption, living in boarding house, young women

Korespondensi: Fajar Ari N. Laboratorium IImu Gizi Fakultas Kedokteran Universitas Brawijaya Malang, Jl. Veteran 65145 Malang Tel. 081330736005 Email:fanmerah@gmail.com

DOI: http://dx.doi.org/10.21776/ub.jkb.2018.030.01.11 


\section{PENDAHULUAN}

Overweight dan obesitas adalah merupakan permasalahan kesehatan global yang disebabkan karena gaya hidup yang mencakup pola makan dan tingkat aktivitas fisik yang tidak sesuai (1). Seiring dengan perkembangan zaman angka kejadian overweight dan obesitas di negara-negara maju semakin meningkat. Hasil survei tahun 2005 menunjukkan adanya peningkatan obesitas pada mahasiswa dimana 3 dari 10 mahasiwa mengalami kelebihan berat badan (2).

Ditinjau dari umur, usia 17 atau 18 tahun - 21 atau 22 tahun termasuk ke dalam kategori remaja akhir, sehingga jika dilihat berdasarkan kategori tersebut mahasiswa dapat digolongkan sebagai remaja akhir (3). Prevalensi obesitas remaja usia 12 - 19 tahun di Amerika Serikat menurut CDC tahun 2009 - 2010 telah mencapai 18,4\% (4). Berdasarkan Riset Kesehatan Dasar (Riskesdas) tahun 2013, prevalensi overweight pada remaja usia $16-18$ tahun di Indonesia mengalami peningkatan jika dibandingkan dengan prevalensi tahun 2010 dari 1,4\% menjadi $7,3 \%$. Jawa Timur merupakan provinsi yang masuk ke dalam kategori lima provinsi yang memiliki prevalensi overweight di atas dari prevalensi nasional pada tahun 2013 (5). Prevalensi overweight dan obesitas remaja putri usia 15 - 19 tahun di Kota Malang berdasarkan profil pangan dan gizi kota Malang pada tahun 2013 sebesar 8,82\% dan 2,94\% dimana prevalensi overweight tersebut lebih tinggi jika dibandingkan dengan prevalensi overweight nasional (6).

Tingkat konsumsi junkfood pada remaja saat ini tergolong tinggi, dimana rata-rata remaja mengkonsumsi junk food 3 sampai 4 kali dalam sebulan (7). Fast food ataupun junk food identik dengan makanan yang tinggi kalori dan rendah mikronutrien seperti vitamin, mineral, asam amino, dan serat. Kandungan kalori dan gula yang tinggi pada junk food tersebut dapat memberikan kontribusi terhadap kejadian obesitas (8).

Arianto mengatakan mahasiswa indekos memiliki frekuensi konsumsi mi instan rata-rata 3 kali sehari (9). Ansari juga mengatakan bahwa mahasiwa yang tinggal jauh dari orang tua memiliki tingkat konsumsi buah dan sayur yang rendah (10). Berdasarkan penelitian tersebut dapat disimpulkan bahwa tempat tinggal menjadi salah satu faktor yang mempengaruhi pola makan pada remaja.

Berdasarkan uraian di atas peneliti tertarik melakukan penelitian mengenai konsumsi junk food dan serat pada remaja putri overweight dan obesitas yang indekos.

\section{METODE}

\section{Subjek Penelitian}

Penelitian ini adalah penelitian kualitatif dengan bentuk diskriptif kualitatif. Format penelitian diskriptif kualitatif merupakan penelitian yang memberikan gambaran secara cermat mengenai keadaan atau gejala yang terjadi pada suatu individu atau kelompok tertentu (11).

Informan dalam penelitian ini adalah remaja putri overweight dan obesitas yang indekos di wilayah Sumbersari dan Kerto, Malang dengan alasan pemilihan informan sebagai berikut: (a) Remaja dengan overweight dan obesitas dengan rata-rata usia 17 - 21 tahun berdasarkan IMT atau IMT/U, (b) Tinggal indekos, (c) Jenis kelamin perempuan, (d) Tidak sedang menjalani diet khusus (e) Bersedia menjadi responden. Selain informan tersebut terdapat juga informan lain sebagai triangulasi yaitu teman indekos dan teman kampus atau teman sekolah informan.

\section{Prosedur Penelitian}

Pencarian informan dilakukan dengan tahapan skrining awal berdasarkan status gizi informan. informan yang memiliki status gizi overweight atau obesitas kemudian dicocokkan dengan kriteria inklusi lainnya. Informan yang telah sesuai dengan kriteria inklusi kemudian dijelaskan secara mendetail mengenai penelitian yang akan dilaksanakan. Bagi informan yang yang bersedia mengikuti penelitian ini dipersilakan untuk menandatangani formulir informed consent.

Penggalian data mengenai berat badan dan tinggi badan informan dilakukan melalui pengukuran antropometri yang dibantu dengan satu orang enumerator D3 gizi. Data karakteristik informan seperti usia, pendidikan, frekuensi, jenis serta jumlah junk food yang dikonsumsi, frekuensi, jenis serta jumlah serat yang dikonsumsi, alasan mengkonsumsi junk food, dan alasan kurang mengkonsumsi serat diperoleh dengan metode in-depth interview dengan menggunakan guideline wawancara dan form Semi Quantitative Food Frequency (SQFFQ) junk food dan sumber serat 3 bulan terakhir.

\section{Analisis Hasil Wawancara dan SQFFQ}

Data hasil wawancara dianalisis melalui tahapan reduksi data, penyajian data dan penarikan kesimpulan. Hasil survei SQFFQ dianalisis dengan menghitung rata-rata skor konsumsi perhari, rata-rata berat konsumsi per hari, dan kemudian dihitung menggunakan nutri survey 2007 untuk mengatahui asupan energi yang diperoleh dari mengkonsumsi junkfood dan asupan serat informan.

\section{HASIL}

\section{Karakteristik Informan}

Informan dalam penelitian ini berjumlah 9 orang yang terdiri dari 4 orang mahasiswa yang indekos di Sumbersari dan 5 orang merupakan mahasiswa yang indekos di Kerto. Rentang usia informan yang diperoleh dalam penelitian ini adalah 19-21 tahun. Berdasarkan status gizinya, terdapat 3 orang informan yang mengalami overweight dan 6 orang informan yang mengalami obesitas. Wawancara juga dilakukan terhadap 14 orang informan lain sebagai triangulasi yang terdiri dari teman indekos informan utama dan teman kampus informan utama.

\section{Frekuensi Konsumsi Junk Food}

Berdasarkan wawancara dengan 9 orang informan diketahui bahwa rata-rata frekuensi konsumsi junk food remaja putri overweight dan obesitas yang indekos adalah lebih dari 1 kali seminggu, bahkan ada yang mengaku hampir setiap hari. Hasil tersebut termasuk ke dalam kategori tinggi (7). Hal ini dibuktikan dengan kutipan informan sebagai berikut:

"ya hampir setiap hari mbak" (11, 12, 13, 13 Oktober 2015)

"ya seminggu pasti kalau gak sekali dua kali lah pasti pernah" (14, 14 Oktober 2015; 18, 19, 11 Desember 2015)

"ya paling 3 kalian sebulan" (I6, 17 Oktober 2015)

"ya paling sebulan 4 kalian lah" (17, 3 Desember 2015)

Hal tersebut juga dibuktikan berdasarkan hasil wawancara teman indekos dan teman kampus informan sebagai 
berikut:

"wah sering banget mbak, dia emang suka ngemil, kalau gorengan itu hampir tiap hari kita di kosan beli" (T1I3, 14 Oktober 2015)

"tiga kalian ada seminggu" (T1/2, 15 Oktober 2015).

Jenis Junk Food yang Sering Dikonsumsi

Hasil wawancara menunjukkan bahwa jenis junk food yang dikonsumsi oleh informan beragam sesuai dengan kesukaan informan, antara lain sebagai berikut:

"yang paling sering ayam krispi si mbak biasanya...paling jajan teh racek" (I1, 13 Oktober 2015)

" cilok kayak gitu kalau pas pulang kampus mbak" (I1, 13 Oktober 2015; 14, 14 Oktober 2015; 16, 17 Oktober 2015; 18, 11 Desember 2015)

"gorengan kayak weci, singkong keju...risoles gitu kalau gak sosis solo" (I2, 13 Otober 2015)

"yang sering itu mie mbak" (I3, 13 Oktober 2015; 19, 11 Desember 2015)

"ee kentang goreng, $\boldsymbol{K F C}^{\prime}(15,17$ Oktober 2015)

“donat, cake kayaknya" (17, 3 Desember 2015)

Selain wawancara tersebut, peneliti juga melakukan SQFFQ terhadap 9 orang informan untuk mengatahui ratarata skor konsumsi junk food oleh informan. Hasil analisa skor SQFFQ diketahui bahwa jenis junk food yang sering dikonsumsi adalah fried chicken yang dikonsumsi oleh 8 informan dengan rata-rata skor konsumsi 0,38 , mie instan yang dikonsumsi 8 orang dengan rata-rata skor konsumsi 0,09 , tahu bakso dikonsumsi 6 orang dengan rata-rata skor konsumsi 0,14 , cilok dikonsumsi 6 orang dengan rata-rata skor konsumsi 0,12, martabak telur dikonsumsi 7 orang dengan rata-rata skor konsumsi 0,08 , terang bulan dikonsumsi 6 orang dengan rata-rata skor konsumsi 0,07 , dan tempe goreng tepung dikonsumsi 4 orang dengan rata-rata skor konsumsi 0,06.

Fried chicken memperoleh hasil skor konsumsi paling tinggi dengan alasan informan mengkonsumsi makanan tersebut karena rasanya yang enak, ada kriuk-kriuknya, dan ukurannya lebih besar dibandingkan dengan ayam goreng biasa. Berikut kutipannya.

"ya enak aja mbak, kalau beli ayam yang biasa itu tu rasanya gimana gitu mbak, enakan yang krispi kalau perasaanku" (I1, 23 Desember 2015 2015)

"ada kriuk-kriuknya gitu mbak" (I2, 23 Desember 2015 2015)

"jadi keliatan gede gitu lho mbak, kan ada tepungnya" (I2, 23 Desember 2015)

Jenis junkfood lain yang memperoleh skor konsumsi tinggi adalah mi instan. Menurut 2 orang informan alasan mereka mengkonsumsi mi instan karena praktis, mudah dibuat, enak, hemat dan dapat menjadi alternatif di saatsaat tertentu. Hal ini dibuktikan dengan kutipan hasil wawancara sebagai berikut:

"mie itu kan buatnya gampang, ... pas ujan trus mau keluar beli makan males ya udah akhirnya mie mbak" (I1, 23 Desember 2015)

"mie itu kan enak mbak, trus praktis kan mbak, sama sekalian buat hemat, heehee" (12, 23 Desember 2015)

Gorengan juga merupakan jenis junk food yang sering dikonsumsi informan berdasarkan hasil skor konsumsi SQFFQ. Gorengan yang sering dikonsumsi antara lain cilok, weci, tempe goreng tepung dan lain-lain. Menurut 4 orang informan yang sering mengkonsumsi gorengan alasan mereka mengkonsumsi gorengan karena rasanya yang enak, sebagai teman mengerjakan tugas, dapat dikonsumsi bersama-sama dengan teman, serta tersedia disekitar mereka. Berikut kutipannya:

"ya enak aja, kan kayak misal ngerjain tugas gitu kan seringnya jajannya kayak gitu, soalnya kan enak, sambil rame-rame juga sama temen kan enak" (I1, 12, 13, 13 Oktober 2015)

"dikantin kan jajan kayak gitu banyak mbak" (16, 17 Oktober 2015)

\section{Rata-Rata Asupan Energi dari Junk Food}

Hasil SQFFQ menunjukkan bahwa rata-rata asupan energi informan yang diperoleh dari konsumsi junk food adalah 522,1 kkal yang menyumbang sebanyak $20,23 \%$ atau $1 / 4$ dari kecukupan AKG untuk wanita usia 19-29 tahun.

\section{Alasan Mengkonsumsi Junk Food}

Seringnya informan mengkonsumsi beberapa jenis junk food disebabkan karena rasa yang enak, penyajian yang cepat, serta dapat menjadi sarana berkumpul dengan teman-teman. Hal tersebut dapat diketahui berdasarkan hasil wawancara sebagai berikut:

"rasanya kayak pengen ngerasain lagi gitu lho, ketagihan" $(15,17$ Oktober 2015)

"trus juga kan nyajiinnya cepet juga" (16, 17 Oktober 2015)

"kayak ngumpul gitu lho kak, jadi ta junk food ujungujungnya" (14, 14 Oktober 2015)

"ee mungkin favorit aja si" (19, 11 Desember 2015)

Berdasarkan hasil wawancara tersebut diketahui juga bahwa alasan yang paling dominan dalam mengkonsumsi junkfood adalah rasa.

Informan juga memiliki beberapa pertimbangan ketika mereka membeli junkfood antara lain adalah rasa, tempat, brand, harga, keinginan, porsi serta adanya diskon, tetapi rasa merupakan alasan utama yang menjadi pertimbangan dalam membelijunkfood. Berikut kutipannya:

"porsinya lebih gede" (I1, 13 Oktober 2015)

"sama rasanya" (I1, I2, I3, 13 Oktober 2015; 14, 14 Oktober 2015; 15,16, 17 Oktober 2015)

"sama kepingin si" (12, 13 Oktober 2015)

"iya si harga" (14, 14 Oktober 2015, 15; 17 Oktober 2015; 18,19, 11 Desember 2015)

"sama diskon, heehee" (I6, 17 Oktober 2015)

"tempatnya harus enak, bersih, trus apa lagi ya, mungkin branded" (17, 3 Desember 2015)

\section{Frekuensi Mengkonsumsi Makanan Sumber Serat}

Rata-rata sebagian informan mengkonsumsi makanan sumber serat 2-3 kali seminggu dan sebagian lagi mengkonsumsi makanan sumber serat hampir setiap hari. Hasil tersebut menunjukkan bahwa frekuensi konsumsi makanan sumber serat informan masih tergolong rendah. Berikut kutipannya:

"kalau seminggu ya 6 kalian ada" (I1, 13 Oktober 2015)

"seminggu 3 kalian lah" (I2, 13 Oktober 2015; 17, 3 Desember 2015; 19, 11 Desember 2015)

"seminggu bisa 5 kalian" (13, 13 Oktober 2015) 
"kalau aku ya setiap hari makan sayur" (14, 14 Oktober 2015; 18, 11 Desember 2015)

"seminggu itu minimalnya 2 kali" (I5, 17 Oktober 2015; 17, 3 Desember 2015)

Hasil tersebut juga didukung berdasarkan hasil wawancara triangulasi dengan teman kampus dan teman indekos informan. Berikut kutipannya:

“...jarang mbak, gak seberapa suka sayur, jadi jarang dia makan..." (T117, 3 Desember 2015)

"dua, tiga kalian mbak paling seminggu" (T2I2, 15 Oktober 2015)

\section{Jenis Makanan Sumber Serat yang Sering Dikonsumsi}

Jenis makanan sumber serat yang sering dikonsumsi oleh informan beragam, berdasarkan kesukaan informan. Hal ini dibuktikan dari hasil wawancara sebagai berikut:

"ya kayak urap-urap sama tumisan" (I1, 13 Oktober 2015)

"capcay, bayam, sama sop" (I2, I3 13 Oktober 2015)

"kangkung sama sawi" (14, 14 Oktober 2015; 1517 Oktober 2015)

"jus jambu mbak sama jus strawbery" (16, 17 Oktober 2015)

"touge sama itu Iho touge, bayam" (17, 3 Desemmber 2015)

"selada dimakan mbak" (I8, 11 Desember 2015)

"jus terong belanda, campur tomat ataupun wortel" (19,11 Desember 2015)

Peneliti juga menghitung rata-rata skor konsumsi yang dikonsumsi oleh informan dengan menggunakan metode SQFFQ dan diperoleh hasil adalah selada lalapan dikonsumsi 6 orang informan dengan rata-rata skor konsumsi 0,60, sawi hijau sebagai campuran nasi goreng atau mie dikonsumsi 7 orang informan dengan rata-rata skor konsumsi 0,21 , kangkung dikonsumsi oleh 7 orang informan dengan rata-rata skor kosumsi 0,09, dan bayam dikonsumsi 6 orang informan dengan rata-rata skor konsumsi 0,16.

Hasil skor konumsi menunjukan bahwa jenis makanan sumber serat yang sering dikonsumsi informan mencakup selada, sawi, kangkung dan bayam. Tingginya skor ratarata konsumsi terhadap jenis makanna tersebut disebabkan karena sayuran tersebut adalah sayuran yang sering tersedia disekitar informan. Berikut kutipannya:

"kan Ialapan, paling sayurnya selada 1 lembar kalau gak timun 1 potong..." (I8, 11 Desember 2015)

"paling sawi dicampur sama nasi goreng" (I8, 11 Desember 2015)

"di warung makan campur juga seringnya sayuran itu" (12,13 Oktober 2015)

\section{Rata-Rata Asupan Serat}

Hasil SQFFQ menunjukkan bahwa rata-rata asupan serat informan adalah 3,91 gram. Hasil tersebut masih sangat kurang jika dibandingkan dengan kecukupan AKG untuk wanita usia 19-29 tahun yaitu 32 gram atau FDA yang menganjurkan untuk mengkonsumsi 25 gram serat sehari.

\section{Alasan Rendahnya Konsumsi Serat}

Tingkat konsumsi serat informan jika dilihat berdasarkan analisis SQFFQ menunjukkan hasil yang cukup rendah.
Hasil wawancara diketahui bahwa alasan rendahnya konsumsi makanan sumber serat pada informan disebabkan karena keterbatasan ketersediaan makanan sumber serat disekitar mereka, informan tidak menyukai sayur, sayur yang dijual di sekitar mereka tidak sesuai dengan selera mereka, dan adanya rasa bosan karena menu sayur yang dijual di sekitar mereka kurang beragam. Berikut kutipannya:

"bosen iya, kan adanya itu-itu aja mbak" (I1, 13 Oktober 2015)

"carinya susah mbak kebanyakan lalapan" (12, 13, 13 Oktober 2015; 16, 17 Oktober 2015; 17, 3 Desember 2015; 18, 11 Desember 2015)

"gak begitu suka soalnya" (I5, 17 Oktober 2015; 17, 3 Desember 2015)

"sayur itu paling udah kematengan kalau misalnya belibeli kayakgitu" (19,11 Desember 2015)

Tetapi alasan yang paling dominan adalah karena keterbatasan ketersediaan makanan sumber serat di sekitar mereka.

\section{DISKUSI}

\section{Frekuensi Konsumsi Junk Food}

Frekuensi konsumsi junk food pada remaja putri overweight dan obesitas yang indekos berdasarkan hasil wawancara dapat dikatakan tinggi. Menurut Arif konsumsi junkfood dengan frekuensi 1-2 minggu sekali sudah masuk ke dalam ketegori tinggi. Rasa yang enak, tersedianya junk food di sekitar informan, keinginan serta adanya kebiasaan jajan yang cenderung mengarah ke junk food di kalangan informan merupakan penyebab tingginya frekuensi junk food oleh informan.

Era globalisasi berdampak pada pola konsumsi junk food yang kini menjadi gaya hidup dikalangan remaja. Pola makan "kebarat-baratan" (eropa) dengan kandungan lemak tinggi, kalori tinggi dan rendah serat merupakan makanan yang menarik bagi remaja. Remaja juga cenderung memiliki kebiasaan jajan dan ngemil yang dilakukan dengan teman baik disekolah maupun di luar sekolah. Pola konsumsi makanan yang sering tidak teratur, sering jajan, sering tidak makan pagi dan sama sekali tidak makan siang berpengaruh terhadap kebiasaan kosumsi junk food dikalangan remaja (12).

\section{Jenis Junk Food yang Sering Dikonsumsi}

Jenis junk food yang sering dikonsumsi informan dalam penelitian ini beragam diantaranya fried chicken, mie instan, tahu bakso, cilok, jamur krispi, martabak telur, weci, terang bulan, kentang goreng dan tempe goreng tepung. Di Indonesia, fried chicken menjadi salah satu makanan yang digemari di masyarakat karena penyajiannya yang cepat dan praktis, tidak membutuhkan waktu lama, rasanya enak, sesuai dengan selera serta konsumsi fried chicken dapat yang dapat menaikan status sosial remaja (13).

Alasan serupa juga ada pada mie instan. Mie instan merupakan jenis junk food yang sering dikonsumsi informan karena rasanya yang enak, praktis dan hemat karena harganya yang terjangkau Selain praktis dan harganya yang relative murah, mie instan memiliki rasa yang dapat memenuhi selera berbagai kelompok masyarakat. Hal tersebut menyebabkan mie instan 
mampu menggeser peranan makanan pokok tradisional seperti jagung, ubi kayu, ubi jalar dan sagu (9).

Jenis junk food lain yang sering dikonsumsi informan adalah jenis junk food lokal seperti tahu bakso, cilok, jamur krispi, martabak telur, weci, terang bulan, kentang goreng dan tempe goreng tepung. Gorengan merupakan jenis junk food lokal yang menyumbang energi lebih banyak dibandingkan dengan western junk food (14). Tingginya tingkat konsumsi gorengan dimasyarakat disebabkan karena rasa dari gorengan yang gurih dan dapat dinikmati bersama-sama saat informan mengerjakan tugas dengan teman-teman mereka. Gorengan juga merupakan jajanan yang paling mudah ditemui dikantin-kantin atau tempat sekitar kampus atau sekolah (13). Harga yang relatif murah juga menjadi alasan yang menyebabkan tingginya tingkat konsumsi junkfood dikalangan remaja (14).

\section{Rata-Rata Asupan Energi dari Junk Food}

Junk food identik dengan makanan yang tinggi kalori dan rendag mikronutrien seperti vitamin, mineral asam amino dan serat (9). Rata-rata asupan energi harian informan yang diperoleh dari SQFFQ diketahui sebesar 522,1 kkal. AKG tahun 2013 dituliskan bahwa untuk wanita usia 19-29 tahu kecukupan energinya sebesar 2250 kkal, sehingga jika dibandingkan dengan kecukupan tersebut rata-rata asupan energi yang dikonsumsi informan menyumbang 23,20\% AKG atau $1 / 4$ dari kecukupan AKG.

Sebuah penelitian yang dilakukan di Amerika mengatakan bahwa konsumsi junk food sepertiga dari kebutuhan sehari memiliki kontribusi terhadap kejadian obesitas (15). Penelitian lain yang dilakukan di kota Semarang mengatakan bahwa konsumsi junk food $>300 \mathrm{kkal} /$ perhati mampu meningkatkan resiko terjadinya obesitas pada remaja (14).

Literature ilmiah mengatakan bahwa alasan utama yang menjadikan junk food berkontribusi terhadap kejadian obesitas adalah harganya yang murah, porsinya besar serta kepadatan energi yang tinggi (16). Hasil wawancara dalam penelitian diketahui bawa beberapa informan mengaku mengkonsumsi burger dengan isi daging, telur dan keju. Beberapa diantara mereka juga mengatakan bahwa mereka sering membeli junk food dalam jumlah besar dan mengkonsumsi minuman tinggi energi. Hal ini menyebabkan tingginya asupan energi yang diperoleh darijunkfood yang dikonsumsi oleh informan.

\section{Alasan Mengkonsumsi Junk Food}

Rasa yang enak merupakan asalan yang paling umum yang membuat junk food disukasi oleh masyarakat, begitu pula oleh informan dalam penelitian ini. Kandungan minyak, garam dan gula pada junk foof merupakan salah satu faktor yang menyebabkan rasa dari junk food menjadi begitu digemari (8). Junk food mampu menawarkan berbagai macam menu makanan yang bervariasi dengan rasa yang sangat enak dan lezat sehingga dapat sesuai dengan selera siapa saja yang mengkonsumsinya (7).

Alasan lain yang menyebabkan remaja menjadi gemar mengkonsumsi junk food adalah karena beberapa remaja menjadikan junk food sebagai makanan favorit mereka. Selain itu, resto-reso junk food menjadi tempat yang menarik untuk keluarga dan teman-teman dapat berkumpul (17). Resto-resto junk food saat ini juga menawarkan beberapa kelebihan dimana mereka menyediakan tempat yang santai, nyaman, tata ruang yang menarik, wifi sehingga menjadi daya tarik lebih bagi sebagian pembeli.

Brand dari suatu makanan juga dapat mempengaruhi tingkat konsumsi junk food dimasyarakat. Remaja akan cenderung menkonsumsi makanan dengan merk-merk bergengsi sebagai ekspresi diri dalam pergaulan (18). Tren yang terjadi pad apergaulan remaja saat ini adalah mereka akan cenderung melalukan selfie atau foto-foto yang menunjukkan merk dari suatu makanna yang mereka konsumsi untuk di upload di media social yang mereka miliki dengan tujuan agar teman-teman mereka mengetahui bahwa mereka telah makan ditpat atau mengkonsumsi makanan dengan brand tersebut.

Harga, besar porsi serta diskon juga berkontribusi terhadap kebiasaan konsumsi junk food pada remaja. Seiring perkembangan zaman, porsi dari dari makanan juga mengalami perubahan. Perubahan-perubahan ukuran porsi selama tiga decade terakhir tersebut berkontribusi terhadap kejadian obesitas. Informan mengatakan bawa harga yang relative murah, porsi yang besar merupakan salah satu pertimbangan mereka dalam memilih atau mengkonsumsi junk food. banyaknya diskon yang ditawarkan oleh perusahaan-perusahaan makanan guna mempromosikan produk makanan mereka terbukti dapat berpengaruh terdapat meningkatnya keinginan membeli seeorang (19).

\section{Frekuensi Konsumsi Makanan Sumber Serat}

Hasil penelitian menunjukkan bahwa rata-rata frekuensi konsumsi makanan sumberserat pada informan masih tergolong rendah, dimana infroman mengkonsumsi buah atau sayur 2-3 kali seminggu walaupun terdapat beberapa informan yang mengkonsumsi hampir setiap hari. Sejak tahun 1990 Dietary Guidelines for Americans telah merekomendasikan bahwa konsumsi minimal buah adalah 2 kali/hari dan konsumsi minimal sayur adalah 3 kali/hari untuk setara dengan mengkonsumsi buah dan sayur 5 kali/hari. Tetapi berbagai penelitian menyebutkan kebanyakan remaja tidak dapat memenuhi rekomendasi tersebut (20).

Preferensi atau kesukaan seseorang terhadap makanan merupakan salah satu faktor yang mempengaruhi tingkat konsumsi buah dan sayur. Kesukaan terhadap makanan mempunyai pengaruh terhadap pemilihan makanan (27). Salah satu informan dalam penelitian ini juga mengtakan alasan jarang mengkonsumsi makanan sumber serat seperti buah dan sayur karena dia tidak terlalu menyukai bah dan sayur.

Kesukaan seseorang terhadap suatu makanan juga dapat dipengaruhi oleh rasa, penampilan, tekstur, dan aroma dari suatu makanan. Daya tarik sensorik diketahui sebagai salah satu faktor yang paling penting dalam kaitannya terhadap pemilihan makanan (21). Hal ini juga ditemui pada informan saat wawancara. Salah satu informan mengatakan bahwa dia cenderung tidak menyukai sayur yang dijual disekitar tempat indekosnya karena sayur tersebut terlalu matang memasaknya. Hal ini mengharuskan informan untuk memasak sayur sendiri. Keterbatasan waktu yang ada menyebabkan informan tidak dapat masak setiap hari, sehingga asupan sayur informan menjadi kurang.

Sikap seseorang terkait gizi juga dapat mempengaruhi pola makan seseorang. Seseorang dengan pengetahuan terkait 
gizi dalam makanan yang lebih luas cenderung akan menggunakan aspek gizi dalam memilih suatu makanan (21). Hasil penelitian ini diketahui bahwa informan yang mengkonsumsi sayur atau buah hampir setiap hari dikarenakan mereka meyakini bahwa konsumsi sayur dan buah baik bagi sistem pencernaan mereka. Informan mengatakan jika mereka tidak mengkonsumsi sayur maka mereka cenderung akan mengalami ganggguan buang air besar. Selain itu terdapat juga informan yang mengatakan bahwa konsumsi sayur menjadikan tubuh terasa lebih segar. Sehingga meskipun mereka merasa kesulitan untuk memnuhi kebutuhan sayur dan buah, mereka tetap mengusahakan untuk mengkonsumsi sayur setiap hari.

Meskipun informan tinggal jauh dari rumah atau indekos, tetapi pola makan keluarga akan tetap mempengaruhi pola makan mereka. Orang tua atau guru dapat menjadi model dalam perilaku diet sehat bagi anak-anaknya (20). Hasil wawancara dengan informan juga diketahui bahwa beberapa informan yang mengkonsumsi sayur hampir setiap hari mengaku bahwa mereka memang sudah terbiasa mengkonsumsi sayur sejak mereka masih tinggal dirumah.

Selain orang tua, teman juga memiliki pengaruh yang sangat kuat terhadap pemilihan makanan. Perilaku remaja mulai banyak dipengaruhi oleh teman, termasuk perilaku makan. Remaja cenderung memilih makananmakanan yang dapat diterima di kalangan peer group mereka (22). Hasil wawancara juga menemukan bahwa informan yang memiliki frekuensi konsumsi sayur lebih sering juga dipengaruhi karena seringnya masak bersama dengan teman-teman mereka di tempat indekos. Teman mereka sering mengajak dan memasakan sayur seperti sop atau jenis sayuran lainnya untuk mereka yang kemudian dikonsumsi secara bersama-sama.

Ketersedian buah dan sayur disekitar tempat tinggal informan memiliki pengaruh yang sangat kuat terhadap konsumsi buah dan sayur oleh informan. Tersedianya buah dan sayur di rumah akan mendorong remaja untuk mengkonsumsi sayur dan buah tersebut. Rendahnya frekuensi konsumsi makanan sumber serat terutama sayur dan buah pada informan sebagian besar disebabkan karena ketersediannya yang terbatas. Informan mengatakan bahwa lingkungan tempat tinggal mereka cenderung lebih dominan menjual lalapan yang minim sayur dari pada warung nasi campur. Sehingga informan menjadi merasa kesulitan untuk memperoleh sayur yang dampaknya menjadi rendahnya konsumsi sayur pada informan.

\section{Jenis Makanan Sumber Serat yang Sering Dikonsumsi}

Selada, sawi, kangkung merupakan jenis makanan sumber serat yang paling sering dikonsumsi oleh informan. Seringnya informan mengkonsumsi selada disebabkan karena informan sering mengkonsumsi lalapan. Selain selada, sawi hijau, kangkung, dan bayam merupakan jenis makanan sumber serat yang frekuensi konsumsinya sering pada informan. Hal tersebut disebabkan karena sawi, kangkung dan bayam adalah jenis sayuran yang paling sering ada di sekitar mereka. Mereka mengkonsumsi sawi ketika mereka mengkonsumsi nasi goreng atau berbagai macam mie yang didalamnya terdapat sawi sebagai campurannya. Sedangkan kangkung dan bayam merupakan jenis sayuran yang paling umum dijual di warung nasi campur didekat tempat tinggal informan.

\section{Rata-Rata Asupan Serat}

Berdasarkan hasil SQFFQ diketahui bahwa rata-rata asupan serat informan baru mencapai 3,91 gram. Hal tersebut menunjukkan masih rendahnya asupan serat pada informan baik jika dibandingkan dengan kebutuhan AKG usia 19-29 tahun yaitu 32gram/hari maupun berdasarkan FDA yaitu 25 gram/hari (23). Asupan gula sukrosa yang tinggi, asupan lemak yang tinggi serta rendahnya asupan serat merupakan faktor resiko yang dapat menyebabkan terjadinya obesitas sentral (24). Al-Rethaiaa tahun 2010 juga mengatakan bahwa pola makan yang tidak teratur, konsumsi buah dan sayur yang rendah serta seringnya mengkonsumsi snack memberikan dampak yang negatif terhadap indeks massa tubuh (IMT) (25). Menurut hasil SQFFQ beberapa informan memang telah mengusahakan untuk mengkonsumsi makanan sumber serat setiap hari. Tetapi usaha tersebut juga masih kurang cukup untuk memenuhi kebutuhan serat mereka karena makanan sumber serat yang sering dikonsumsi adalah selada lalapan yang dari segi kuantitas begitu sedikit.

\section{Alasan Rendahnya Konsumsi Serat}

Sebagian besar yang menjadi hambatan informan dalam mengkonsumsi serat adalah keterbatasan makanan sumber serat yang memang terbatas. Ketersediaan pangan ditingkat keluarga atau masyarakat sangat mempengaruhi kebiasaan makan seseorang, dimana terjadinya masalah gizi dimasyarakat salah satunya disebabkan karena ketersediaan pangan yang kurang memadai (26). Beberapa informan mengatakan bahwa sebenarnya mereka memiliki keharusan pada diri mereka untuk mengupayakan mengkonsumsi sayur setiap hari, namun keterbatasan ketersediaan sayur menyebabkan mereka tidak dapat mengkonsumsi sayur. Kesibukan informan juga menjadikan mereka tidak sempat untuk masak atau menyediakan makanan sumber serat untuk informan sendiri.

Kesukaan informan terhadap sayur dan buah juga akan mempengaruhi tingkat konsumsi buah dan sayur informan. Sedangkan preferensi atau kesukaan itu sendiri akan dipengaruhi oleh rasa, penampilan, tekstur, dan aroma dari suatu makanan (21). Salah satu informan dalam penelitian ini mengatakan bahwa alasan dia tidak mengkonsumsi sayur dan buah adalah karena dia tidak terlalu menyukai sayur. Informan tersebut hanya menyukai golongan sayur dan buah tertentu seperti tauge, anggur yang frekuensi konsumsinya juga tidak terlalu sering. Informan lain mengatakan bahwa hambatan yang menjadikannya tidak mengkonsumsi sayur adalah menu sayur yang disajikan di warung sekitar tempat tinggal tidak memenuhi seleranya karnea di masak terlalu matang. Sehingga mempengaruhi frekuensi konsumsi makanan sumber serat oleh informan.

Dari hasil penelitian dapat disimpulkan bahwa frekuensi konsumsi junk food remaja putri overweight dan obesitas yang indekos rata-rata 1 minggu sekali dan masuk ke dalam ketegori tinggi. Jenis junk food yangs sering dikonsumsi oleh informan adalah fried chicken. Hasil rata-rata asupan energi sehari yang diperoleh informan dari konsumsi junk food adalah 23,20\% AKG dan dapat meningkatkan resiko terjadinya obesitas. Frekuensi konsumsi serat remaja putrid overweigt dan obesitas yang indekos rata-rata 2-3 kali seminggu dan masuk ke dalam kategori rendah. Jenis serat yang paling sering dikonsumsi informan adalah 
selada lalapan. Rata-rata asupan serat informan dalam sehari sebanyak 3,91gram/ hari dan masih kurang dari anjuran konsumsi serat sehari yaitu $25 \mathrm{gram} /$ hari. Alasan utama remaja putrid overweight dan obesitas yang indekos mengkonsumsi junk food adalah rasa dari junk food yang enak. Alasan lain yang menyebabkan mereka mengkonsumsi junk food adalah junk food merupakan makanan favorit, penyajiannya cepat, dan junk food dapat

\section{DAFTAR PUSTAKA}

1. Greenway FL. Physiological Adaptations to Weight Loss and Factors Favouring Weight Regain. International Journal of Obesity. 2015; 39(8); 11881196.

2. Sparling PB. Obesity on Campus. Preventing Chronic Disease Public Health Research, Practice, and Policy. 2007; 4(3);A72.

3. World Health Organization. Health for The World's Adolescents A Second Chance in The Second Decade. Geneva, Switzerland: World Health Organization; 2014; hal. 1-2.

4. Ogden $\mathrm{CL}$, Carroll MD, Kit BK, and Flegal KM. Prevalence of Obesity in the United States 2009-2010. NCHS Data Brief: 2012; 82: 1-8.

5. Badan Penelitian dan Pengembangan Kesehatan. Riset Kesehatan Dasar (Riskesdas). Jakarta: Kementerian Kesehatan RI; 2013; hal. 260-262.

6. BAPPEDA Kota Malang. Buku Profil Pangan dan Gizi Kota Malang 2013. Malang: Badan Perencanaan dan Pembangunan Daerah (BAPPEDA) Kota Malang; 2013; hal. 15-16.

7. Arief E, Syam A, dan Dachlan DM. Konsumsi Fast Food Remaja di Restoran Fast Food, Makassar Town Square. Media Gizi Masyarakat Indonesia. 2011; 1(1): 41-45.

8. Ashakiran and Deepthi R. Fast Food and Their Impact on Health. Journal of Krishna Institute of Medical Science University. 2012; 1(2): 7-15.

9. Arianto NT. Pola Makan Mie Instan: Studi Antropologi Gizi pada Mahasiswa Antropologi Fisip Unair. BioKultur. 2013; 2(1): 27-40.

10. Ansari WE, Stock C, and Mikolajczyk RT. Relationships Between Food Consumption and Living Arrangements Among University Students in Four European Countries. Nutrition Journal. 2012; 11(28): 1-7.

11. Febriani PH. Pemberian Motivasi Kepala Perpustaaan dalam Meningkatkan Prestasi Kerja Perpustakaan di UPT Perpustakaan IAIN Sukarta. Jurnal IImu Perpustakaan. 2012; 1(1): 175-184.

12. Merawati D dan Kinanti RG. Prilaku Makanan pada Siswa Obesitas. Jurnal IPTEK Olahraga. 2005; 7(3): 182-192.

13. Kristianti N, Sarbini D, dan Mutalazimah. Hubungan Pengetahuan Gizi dan Frekuensi Fast Food dengan Status Gizi Siswa Negeri 4 Surakarta. Jurnal Kesehatan. 2009; 2(1): 39-47.

14. Pramono A dan Sulchan M. Kontribusi Makanan Jajan menjadi sarana berkumpul dengan teman-teman. Alasan utama rendahnya konsumsi serat pada remaja putrid overweight dan obesitas yang indekos adalah keterbatasan ketersediaan makanan sumber serat di sekitar mereka. Alasan lain rendahnya tingkat konsumsi serat adalah informan tidak menyukai sayur, sayur yang dijual tidak sesuai dengan selera informan, dan adanya rasa bosan karena variasi sayuran yang terbatas disekitar mereka.

dan Aktivitas Fisik terhadap Kejadian Obesitas pada Remaja di Kota Semarang. Jurnal Gizi Indonesia. 2014; 2(2): 59-65.

15. Andair LS and Popkin BM. Are Child Eating Patterns Being Transformed Globally? Obesity Research. 2005; 13(7): 1281-1299.

16. Mair SJ, Pierce M W, and Teret SP. The Use of Zoning to Restrict Fast Food Outlets: A Potential Strategy to Combat Obesity. Washington: Georgetown Universities; 2005; hal. 10-19.

17. Alamsyah Y. Antisipasi Krisis Global Bisnis Fast Food Ala Indonesia. Jakarta: PT. Elex Media Komputindo Kompas Gramedia; 2009; hal. 12-15.

18. Anggraini RDP dan Legowo M. Praktek Konsumtif Mahasiswa Bidik Misi. Paradigma. 2014; 2(2): 1-6.

19. Nusair K, Yoon HJ, Naipaul S, and Parsa HG. Effect of Price Discount Frames and Levels on Consumers Perceptions in Low End Service Industries. International Journal of Contemporary Hospitality Management. 2010; 22(6): 814-835.

20. Bahria dan Triyanti. Faktor-Faktor yang Terkait dengan Konsumsi Buah dan Sayur pada Remaja di 4 SMA Jakarta Barat. Jurnal Kesehatan Masyarakat Andalas. 2010; 4(2): 63-71.

21. Vabe M and Hansen $\mathrm{H}$. The Relationship between Food Preference and Food Choice: A Theoretical Discussion. International Journal of Business and Social Science. 2014; 5(7): 145-157.

22. Oktaviani WD, Saraswati LD, dan Rahfiludin MZ. Hubungan Kebiasaan Konsumsi Fast Food, Aktivitas Fisik, Pola Konsumsi, Karakteristik Remaja dan Orang Tua dengan Indeks Massa Tubuh (IMT) (Studi Kasus pada Siswa SMA Negeri 9 Semarang Tahun 2012). Jurnal Kesehatan Masyarakat. 2012; 1(2): 542-553.

23. Slavin J. Fiber and Prebiotics: Mechanisms and Health Benefit. Nutrients. 2013; 5(4): 1417-1435.

24. Burhan FZ, Sirajuddin S, dan Indriasari R. Pola Konsumsi terhadap Kejadian Obesitas Sentral pada Pegawai Pemerintahan di Kantor Bupati Kabupaten Jeneponto. Jurnal Media Kesehatan Masyarakat Indonesia. 2013; 9(1): 1-14.

25. Al-Rethaiaa AS, Fahmy AE, and Al-Shwaiyat NMA. Obesity and Eating Habits among Collage Students in Saudi Arabia: A Cross Sectional Study. Nutrition Journal. 2009; 9: 39-48.

26. Dewantari NM dan Widiani A. Fruits and Vegetables Consumption Pattern in School Children. Jurnal Skala Husada. 2011; 8(2): 119-125. 